\title{
URUF IN ISLAMIC LAW PERSPECTIVE
}

\author{
Tarmizi \\ Department of Akhwalus Syakhsiyyah, Institut Agama Islam (IAI) As'adiyah Sengkang \\ Veteran Street No. 46, Wajo, Indonesia. 90914 \\ Email: tarmizitahir0@gmail.com
}

\begin{abstract}
This paper discusses "Uruf in the perspective of Islamic law" by revealing problems, namely: (1) What is the position of uruf in istinbath of Islamic law; and (2) How is the application of uruf in Islamic Sharia laws. The position of uruf in istinbath of Islamic law is very important and can be a basis for legal considerations. The law of fighiyyah states that custom is punishable. Meanwhile, the application of uruf in Islamic Sharia laws is a source of law, especially in matters of muamalah, munakahah, and other social relations. Islamic law, which is closely related to interaction with fellow humans, is greatly influenced by the customs in society.
\end{abstract}

Keywords: custom, istinbath, uruf

\begin{abstract}
Abstrak: Tulisan ini membahas tentang "Uruf dalam perspektif hukum Islam” dengan mengungkapkan masalah yaitu: (1) Bagaimana kedudukan uruf dalam istinbath hukum Islam; dan (2) Bagaimana penerapan uruf dalam hukum-hukum Syariat Islam. Kedudukan uruf dalam istinbath hukum Islam sangat penting dan dapat menjadi dasar pertimbangan hukum. Kaidah fiqhiyyah menyebutkan bahwa adat adalah dapat dihukumkan. Sedangkan penerapan uruf dalam hukum-hukum syariat Islam merupakan sumber hukum terlebih dalam masalah muamalah, munakahah, dan hubungan bermasyarakat lainnya. Hukum Islam yang berkaitan erat dengan pergaulan dengan sesama manusia sangat dipengaruhi oleh adat yang terdapat dalam masyarakat.
\end{abstract}

Kata Kunci: adat, istinbath, uruf

\section{Introduction}

A very big influence for humans in religious life and society is culture. To deal with bad forces, humans are forced to protect themselves by creating rules which in essence are indications of how to act and behave in social life. Then it is made the basis of the relationship between certain people so that the behavior of each can be regulated and all of this creates norms or rules. The rules that arise from society according to their needs at one time were called customs. Customs that have legal consequences are called Customary Law (Hakim, 2003).

Customary law has long been in effect in the country. The beginning of its entry into force cannot be determined with certainty, but it can be said that when compared to the Western legal system and Islamic law, customary law is the oldest. Before 1927, customary law conditions were normal, living and developing in Indonesian society. Since 1927 customary law has been studied and observed carefully in the context of the implementation of the Dutch government's political law, after the reception theory was confirmed (Ali, 1998).

Given that customs are norms and values about how to act and behave in social life, in dealing with problems in the midst of society, it is better to refer to the customary law. The validity of rules or laws in a human group depends on the strength of these rules as a guide in regulating behavior and actions. That is, custom functions as long as community members accept it as an indication of appropriate behavior. According to Prof. Dr. Mr. L.J. van Apeldoorn that "de normatieve kracht van het feitelijke gebeuren" means "what is ordinary, is often raised as a rule" (Apeldoorn, 2009). If Islamic law and customary law do not occupy their respective places in society, there will be an imbalance and even tensions in religious and social life. As the tension that occurred between Islamic leaders and traditional leaders in various parts of the country.

Custom without religion will lead to a void of Divine value in a society, so that society will no longer be able to distinguish between good and bad, between benefit and damage. According to Juhaya S. Pradja, not all customary laws which are said to be living laws can provide a sense of justice to the community. There are customary laws which are enforced by customary leaders and some are enforced by social groups (Saebani, 2008). On the other hand, religion without customs, traditions and culture will create 
people who are backward from the values of local wisdom and cultural diversity, so that they are easy to absorb and adopt Western culture. Therefore, it is less accurate to say that culture can be a threat and a factor of poverty in society (Mawardi \& Hidayat, 2002). If culture can bring poverty is still better than a region, even if the country does not have culture at all, that is real poverty. With a principle of "Poor wealth is better than poor culture".

Efforts to harmonize customary law with Islamic law are very important to be implemented immediately. Because in essence customary law and Islamic law have the same goal (maqäsid al-syari'ab), namely to create a life that is safe, peaceful and prosperous.

\section{A. Position of Uruf in Istinbath of Islamic Law}

'Urf is something that has been known by many people and has become a community tradition, either in the form of words, or deeds, or a state of abandonment. According to Yusuf Qardhawi, 'Urf is something that has become a tradition and norm in people's lives, so that they can know him well and get used to it, both in the form of words and deeds, general and specific (Qardhawi, 2003). 'Urfis defined as things that are habituated by humans and apply continuously, from every common action among society. Or 'Urf is an expression known in a community as a special meaning beyond its literal meaning, and at a glance people will understand this meaning. An example of 'Urf which is verbal: people both understand that fish is not called meat or the word walad is only used for boys. Example of ' $U r f$ which is an act: there is no expression of handing over goods when making a sale and purchase transaction.

According to the Forum Karya Ilmiah (2008), there are several types of 'Urf:

1. Based on the shape, there are 'Urf Amali (practice) and 'Urf Qauli (lingual). 'Urf Qauli is an expression used by a community to express a certain meaning, so that when the phrase came out, people understood it with that meaning. Meanwhile, 'Urf Amali is any action that is usually carried out by a group of people and is commonly known among them in their daily activities.

2. Based on the object, there are 'Urf Amm (general) and' Urf Khash (special). 'Urf Amm is a tradition that is well known to all circles. Meanwhile, 'Urf Khash is a habit that is unknown to all groups, but only a certain group.

3. Based on the legality in syara', there are 'Urf Sabih (legal) and 'Urf Fasid (illegal). 'Urf Sabih are things that are commonly known and do not contradict the texts of the Shari'a, do not contain neglect of benefit, and do not have implications for mafsadah (damage). Meanwhile, 'Urf Fasid is a tradition that contradicts some of the provisions of the syara' or its rules.

4. Based on the point of view of its continuity, there are 'Urf Tsabit (static) and 'Urf Mutabaddil (dynamic). 'Urf Thabit is a static tradition, it does not change due to changing space and time, differences of each individual, or because of changing conditions. 'Urf Mutabaddil is a dynamic tradition, subject to change due to differences in space, changing times, and changing conditions.

\section{B. Application of Uruf in Islamic Sharia Laws}

Al-Qur'an and Hadith as sources of figh knowledge, with the help of ulum al-Qur'an and ulum alHadith cover three kinds of laws. First, law concerning the belief of the mukallaf; second, ethical laws, namely the obligation for someone to do good and leave badness; and third, practical laws governing one's actions and speech. 'Urf is a source of law, which was taken by the Hanafi and Maliki Madzhab which was outside the scope of the texts. 'Urf (tradition) are forms of muamalah (relations of interest) which have become customary and have been constant in society. And this is classified as one of the sources of law (ashb) from ushul figh which is taken from the essence of the words of the Prophet Muhammad:

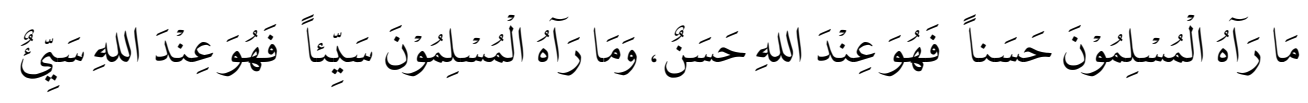

Meaning:

"What is considered good by Muslims, is the view of Allah good, and what is considered bad by them, is also bad in the sight of Allah (HR. Abu Dawud Al-Thayalisi) (al-Makki, 1997). 
Al-Biri in al-Asybah wan Nadhair said:

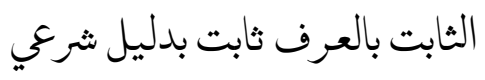

Meaning:

"Something that is defined by 'Urf is deemed established by the argument of syara"" (Ash-Shiddieqy, 1997).

Imam as-Sarkhasi in the book "al-Mabsudh" said:

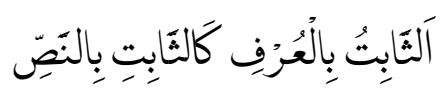

Meaning:

"What is defined according to 'Urf, the status is as determined by the text" (Zahrah, 2008).

The scholars who state that 'Urf is one of the sources of legal istinbath, stipulate that 'Urf can be an argument if there are no texts from the Al-Qur'an and the Sunnah (Hadith). 'Urf gets acknowledged in syara'. Many Imams based their laws on the deeds of the people of Medina. Abu Hanifah and his followers disagreed on a number of laws based on their different 'Urf. Imam Syafii when he came down to Egypt, then he changed some of the laws that had been his opinion when he was in Baghdad, because of the change of 'Urf. Because of this, he has two mahzab, namely the old mabrab and the new mahzab (Zahrah, 2008).

Ulama agree that the form of 'Urf which is accepted for its application is 'Urf Sabih with a general scope that has been in effect from the time of the companions to the next generation, which does not contradict the text of the Shari'a and without ignoring universal basic rules. In detail in its application there are several criteria:

1. First, the entry into force of 'Urf must be muththarid (specified time range) and ghalib (widely enforced).

2. Second, 'Urf is' Urf Amm (known to all groups).

3. Third, the application of 'Urf does not contradict the texts of the Shari'a.

4. Fourth, there is no straightforward expression which contradicts the application of 'Urf.

5. Fifth, 'Urf was formed when the legal action was taken.

Whereas in the rule of Islamic law, 'Urf or custom occupies a very important position in establishing law. In the third rule of Islamic law (fighiyah principles) it is stated:

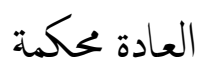

Meaning:

"Habits can become laws" (Saebani, 2009).

The above rules are based on the texts of the Al-Qur'an, including surah Al-A'raf/7:199.

Meaning:

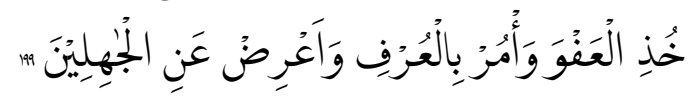

"Take what is given freely, enjoin what is good, and turn away from the ignorant".

A fiqh verse says:

Custom must be considered in syarak; Because many laws are built on it.

To take care of 'Urf in this situation is the same as to take care of benefit. Because, among the things that are beneficial to humans is to determine something that they have known well for a long time and have been used by humans for their affairs for a very long time. Something that is well known and has become a tradition will become a necessity for society which is very difficult to leave. Religion was born to provide convenience and eliminate difficulties. Allah SWT, said in Surah Al-Baqarah/2: 185. 


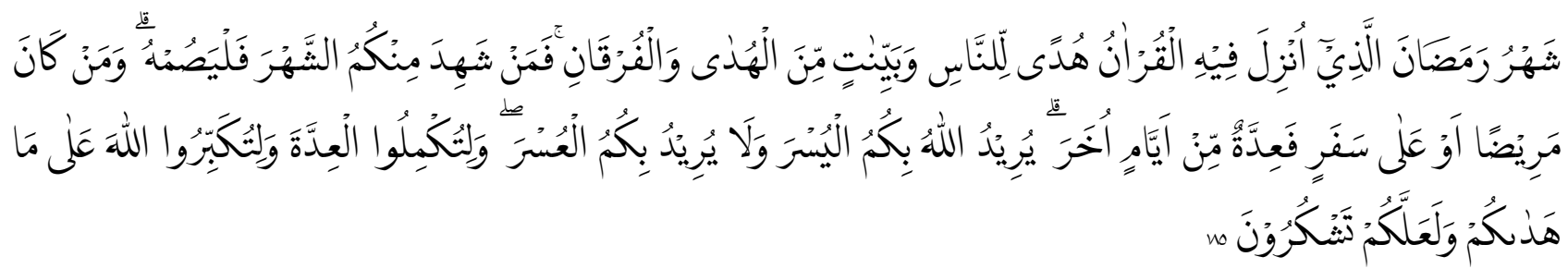

Meaning:

"The month of Ramadhan [is that] in which was revealed the Qur'an, a guidance for the people and clear proofs of guidance and criterion. So whoever sights [the new moon of] the month, let him fast it; and whoever is ill or on a journey - then an equal number of other days. Allah intends for you ease and does not intend for you hardship and [wants] for you to complete the period and to glorify Allah for that [to] which He has guided you; and perhaps you will be grateful".

In another verse, Allah SWT affirming in the Surah Al-Hajj/22:78.

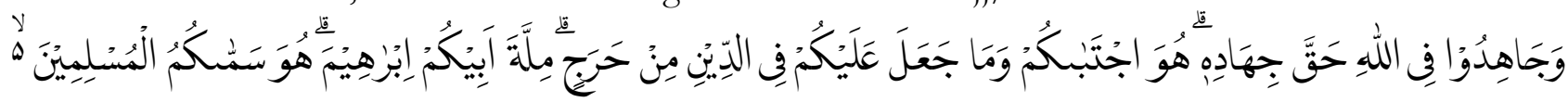

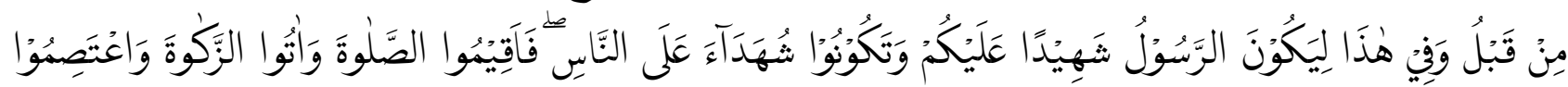

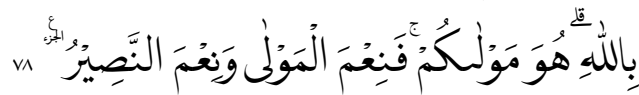

Meaning:

"And strive for Allah with the striving due to Him. He has chosen you and has not placed upon you in the religion any difficulty. [It is] the religion of your father, Abraham. Allah named you "Muslims" before [in former scriptures] and in this [revelation] that the Messenger may be a witness over you and you may be witnesses over the people. So establish prayer and give zakah and hold fast to Allah. He is your protector; and excellent is the protector, and excellent is the helper".

'Urf can be accepted if it does not conflict with a strong text or a convincing ijmak, and will not cause harm. 'Urf which contradicts strong arguments to justify what is haram, invalidates obligations, establishes heresy in religious teachings, or causes negative impacts on human life is unacceptable and should not be used to enact laws, fatwas, or legal decisions. Thus in reality the fatwas of the ulama of fiqh always follow 'Urf who is developing in his society in the event that there is no text that goes on relating to the problem in question. Therefore, a mufti must really master ' $U r f$ in his community. A valuable phrase written by Ibn Abidin reads: "It is imperative for a judge to know legal jurisprudence in general and to know the nature of a case and the conditions of the existing society. In this way, he was able to distinguish between true and false and then matched one case to another. So that he can provide legal provisions for a case (incident) with proper law, and do not provide legal provisions that are contradictory to the actual incident. Likewise, a mufti who gives a fatwa based on 'Urf must know the situation and condition of his community as well as the era. Must know that 'Urf is unique and contradicts the text or not" (Zahrah, 1958).

\section{Conclusion}

'Urf is something that has been known by many people and has become a community tradition, whether it is in the form of words, or deeds, or a state of leaving. According to Yusuf Qardhawi, 'Urf is something that has become a tradition and norm in people's lives, so that they can know him well and get used to it, both in the form of words and deeds, general and special. 'Urf is defined as things that are habituated by humans and apply continuously, from every common action among society. Or 'Urf is an expression known in a community as a special meaning beyond its literal meaning, and at a glance people will understand that meaning. 'Urf is a source of law taken by the Hanafi and Maliki Madzhab which is outside the scope of the texts. 'Urf (tradition) are forms of muamalah (relations of interest) which have become customary and have been constant in society. And this is classified as one of the sources of law (ash) from ushulfiqh which is taken from the essence of the words of the Prophet Muhammad. 


\section{References}

Abady, Yusrie. 2002. "Dinamika Kehidupan Beragama Muslim Pedesaan,” 1st Edition. Jakarta: CV. Rifqi Jaya. Abu Zahra, Muhammad. 1958. "Ushul Fiqh.” Kairo: Dar Al-Fikri Al-Arabiy.

Al-Husaini, Al-Hamid. 1996. "Pembahasan Tuntas Perihal Khilafiyah," $1^{\text {st }}$ Edition. Bandung: Pustaka Hidayah.

Ali, Mohammad Daud. 1998. "Hukum Islam Pengantar Ilmu Hukum dan Tata Hukum Islam di Indonesia," $6^{\text {th }}$ Edition. Jakarta: Rajawali Press.

Ali, Mukti. 1987. "Beberapa Persoalan Agama Dewasa Ini," 1"st Edition. Jakarta: CV. Rajawali.

Al-Qur'an Al-Karim

Apeldoorn, L.J. Van. 2009. "Pengantar Ilmu Hukum,” 33 $3^{\text {rd }}$ Edition. Jakarta: PT. Pradnya Paramita.

Ash-Shiddieqy, Muhammad Hasbi. 1997. "Pokok-Pokok Pegangan Imam Mazhab," $1^{\text {st }}$ Edition. Semarang: PT. Pustaka Rizki Putra.

As-Suyuthi, Jalaluddin Abdurrahman. 1978. “Al- Asybah wa An-Nadzair.” Kairo: Dar Al-Kitab Al-Islamiyah.

Azizy, A.Qodri. 2003. "Reformasi Bermazhab,” 2nd Edition. Jakarta Selatan: PT. Teraju.

Basri, Cik Hasan. 1999. “Kompilasi Hukum Islam dan Peradilan Agama di Indonesia,” 2nd Edition. Jakarta: PT. Logos Wacana Ilmu.

Boisard, Marcel A. 1980. "Humanisme Dalam Islam,” 1't Edition. Jakarta: PT. Bulan Bintang.

Hakim, Abd., Atang., and Jaih Mubarok. 2003. "Metodologi Studi Islam,” 7th Edition. Bandung: PT. Remaja Rosdakarya.

Idham, Muhammad. 2010. "Tradisi Lisan Sebagai Media Pendidikan di Sulawesi Selatan.” Makassar: Balai Penelitian dan Pengembangan Agama Islam.

Khallaf, Abdul Wahhab. 1994. "Ilmu Ushul Fiqh," 1'st Edition. Semarang: Dina Utama.

Lukito, Ratno. 1998. "Pergumulan Hukum Islam dan Adat di Indonesia." Jakarta: INIS.

Madjid, Nurcholish. 1992. "Islam Doktrin dan Peradaban," $1^{\text {st }}$ Edition. Jakarta: PT. Temprint.

Madjid, Nurcholish. 2005. "Fiqh Lintas Agama," $7^{\text {th }}$ Edition. Jakarta: Paramadina.

Qardhawi, Yusuf. 2003. "Membumikan Syariat Islam," 1'st Edition. Bandung: PT. Mizan Pustaka.

Saebani, Beni Ahmad. 2008. "Filsafat Hukum Islam," 1 $1^{\text {st }}$ Edition Bandung: CV. Pustaka Setia.

Saebani, Beni Ahmad. 2009. "Ilmu Ushul Fiqh," 1st Edition. Bandung: CV. Pustaka Setia.

Shihab, Umar. 2003. "Kontekstualitas Al-Qur'an,” 1st Edition. Jakarta: Pena Madani.

Sukardi, Imam., et al. 2003. "Pilar Islam Bagi Pluralisme Modern," $1^{\text {st }}$ Edition. Solo: Tiga Serangkai.

Syamsuddin, Muhammad Din. 2000. "Etika Agama Dalam Membangun Masyarakat Madani,” 1st Edition. Jakarta: PT. Logos Wacana Ilmu, 2000.

Uways, Abdul Hakim. 1998. "Fiqh Statis dan Fiqh Dinamis," $1^{\text {st }}$ Edition. Bandung: Pustaka Hidayah.

Wahid, Marzuki. 2004. ISTIQRO’ Jurnal Penelitian Direktorat Perguruan Tinggi Agama Islam 3.

Wahid, Marzuki. 2007. ISTIQRO'Jurnal Penelitian Direktorat Perguruan Tinggi Agama Islam 6.

Yatim, Badri., and Karya, Soekama. 1998. “Ensiklopedi Mini Sejarah dan Kebudayaan Islam,” 2nd Edition. Jakarta: PT. Logos Wacana Ilmu. 